\title{
PERAN KEPUASAN KERJA TERHADAP KINERJA PADA GURU PEGAWAI NEGERI SIPIL (PNS) DI YOGYAKARTA
}

\author{
Fatwa Tentama \\ Fakultas Psikologi Universitas Ahmad Dahlan \\ J1. Kapas 9 Semaki Yogyakarta \\ fatwa_ten10@yahoo.com
}

\begin{abstract}
The problems faced by organizations is employee performance tends to decline over time resulting ineffectiveness of the organization. One of the factors that affect performance is job satisfaction. This study aims to determine empirically the correlation between job satisfaction and performance of the civil servant teachers. Subjects were 29 civil service teachers both male and female who become permanent employees and has worked at least 1 year in SLB Negeri 1 Bantul Yogyakarta. Data were collected using the Job Satisfaction Scale and the Performance Scale. Pearson's product moment correlation were used to test the relationship between job satisfaction and teacher performance. The results showed that there is a significant positive correlation between job satisfaction and performance of the civil servant teachers $\left(r_{\mathrm{xy}}=.551 ; p=.001\right)$. The more satisfied the teachers, the higher their performance.
\end{abstract}

Keywords: civil servant teachers, job satisfaction, performance

\begin{abstract}
Abstrak
Permasalahan yang sering dihadapi oleh setiap organisasi adalah mengenai kinerja karyawan yang cenderung menurun dari waktu ke waktu yang mengakibatan tidak efektifnya organisasi. Salah satu faktor yang mempengaruhi adalah kepuasan kerja karyawan. Penelitian ini bertujuan untuk mengetahui secara empiris hubungan antara kepuasan kerja dengan kinerja pada guru PNS. Subyek dalam penelitian ini adalah 29 guru PNS baik laki-laki dan perempuan yang telah menjadi pegawai tetap dan sudah bekerja minimal 1 tahun di SLB Negeri 1 Bantul Yogyakarta. Alat pengumpulan data dalam penelitian ini adalah Skala Kepuasan Kerja dan Skala Kinerja. Metode analisis statistik data yang digunakan dalam penelitian ini adalah teknik korelasi product moment dari Pearson untuk menguji korelasi kedua variabel yang diteliti. Hasil penelitian menunjukkan adanya hubungan yang positif dan signifikan antara kepuasan kerja dan kinerja $\left(r_{\mathrm{xy}}=0,551 ; p=0,001\right)$. Semakin guru puas dengan pekerjaannya, maka semakin tinggi kinerjanya.
\end{abstract}

Kata Kunci: guru PNS, kepuasan kerja, kinerja

\section{PENDAHULUAN}

Sumber daya manusia tetap memegang peran penting meskipun peran teknologi semakin dominan di jaman modern ini. Sumber daya manusia menjadi komponen vital dalam sebuah organisasi dalam mencapai tujuannya. Sumber daya manusia itulah yang menentukan keefektifan suatu organisasi agar dapat berjalan dengan baik karena sumber daya manusia itu sendiri mempunyai pengaruh yang sangat besar terhadap kinerja organisasi. Artinya memiliki sumber daya manusia yang mampu memberikan kontribusi yang maksimal menjadi harapan setiap organisasi. Yukl (2009) menyatakan bahwa sumber daya manusia merupakan salah satu faktor yang sangat penting dalam organisasi atau perusahaan sebab sumber daya manusia adalah penentu keberhasilan suatu organisasi. Munandar (2008) menambahkan karyawan merupakan asset utama dalam suatu organisasi dengan kata lain merupakan kekayaan utama organisasi. Mengelola dan mengembang- 
kan sumber daya manusia dengan baik dapat meningkatkan kinerja karyawan sehingga dapat mencapai efektivitas organisasi.

Kinerja dari karyawan perlu diperhatikan dalam upaya mencapai kualitas sumber daya manusia yang baik dan efektif. Keberadaan karyawan dengan kinerja yang tinggi pada organisasi akan mengantarkan organisasi pada suatu kondisi yang menguntungkan. Kinerja karyawan merupakan topik yang multidimensional dan sangat penting untuk kesuksesan organisasi. Karyawan suatu organisasi apabila menunjukkan kinerja yang rendah maka organisasi juga akan terkena dampaknya. Realitanya permasalahan yang sering dihadapi oleh banyak organisasi adalah kinerja karyawan yang cenderung menurun dari waktu ke waktu yang mengakibatan tidak efektifnya organisasi tersebut.

Menurut Menteri Pendayagunaan Aparatur Negara dan Reformasi Birokrasi, sekitar 50 persen dari 4,7 juta PNS yang ada di Indonesia memiliki kualitas rendah, atau tidak memiliki kapasitas yang mamadai (Kusmana, 2012). Ketua Asosiasi Pengusaha Indonesia (Apindo), Djimanto, juga menambahkan bahwa kinerja dan produktivitas Pegawai Negeri Sipil (PNS) di Indonesia sangat rendah bila dibandingkan dengan negara lain sehingga menghambat pembangunan ekonomi (Suara Pembaharuan, 2011).

Selama tahun 2010-2013 dari 4,5 juta PNS, sebanyak 741 orang PNS telah dipecat pemerintah. Pemecatan tersebut terkait dengan pelanggaran disiplin PNS dan yang terbanyak diantaranya adalah tidak masuk kerja (Mizan, 2013). Data menujukkan dari tahun ke tahun kinerja Pegawai Negeri Sipil (PNS) tidak mengalami peningkatan dan sebaliknya banyak yang diminta pensiun dini, mengundurkan diri bahkan dipecat oleh pemerintah karena kinerjanya yang buruk.

Kinerja merupakan semua tindakan atau perilaku yang dikontrol oleh individu dan memberikan kontribusi bagi pencapaian tujuan-tujuan dari organisasi (Rotundo \& Sackett, 2002). Gibson, Ivancevich \& Donelly (2000) menambahkan kinerja adalah hasil kerja yang terkait dengan tujuan organisasi seperti kualitas, efisiensi, dan kriteria keefektifan lain yang dicapai selama periode tertentu melalui usaha yang membutuhkan kemampuan dan keterampilan serta pengalaman. Kinerja sebagai perilaku-perilaku atau tindakantindakan yang relevan terhadap tercapainya tujuan organisasi (Vande, dkk., 2005).

Fakta di atas lebih spesifik juga ditunjukkan pada Pegawai Negeri Sipil (PNS) guru di SLB Negeri 1 Bantul Yogyakarta. Sekolah Luar Biasa Negeri 1 Bantul merupakan Sekolah Luar Biasa (SLB) terbesar di Daerah Istimewa Yogyakarta sebagai wadah untuk mendidik anak-anak berkebutuhan khusus seperti tuna daksa/difabel, tuna rungu, tuna grahita, tuna wicara, penderita retardasi mental, ADHD, autisme, agresif dan lain lain. Perilaku kinerja yang rendah ditunjukkan adalah perilaku bolos kerja, absensi, terlambat mengajar, bekerja/ mengajar seadanya, tugas-tugas yang tertunda, kurangnya komunikasi dan kerjasama dengan atasan dan lain-lain. Sebagai suatu instansi di bidang pendidikan sangat diharapkan guru SLB Negeri. 1 Bantul dapat menunjukkan kinerja yang baik demi mencapai visi, misi dan tujuan pendidikannya dan mendapatkan penilaian kinerja yang baik dari pihak luar. Upaya dalam mencapai tujuan tersebut diperlukan para pegawai yang mempunyai kinerja yang kuat sebagai langkah awal untuk melaksanakan tugastugasnya sebagai pendidik bangsa, apalagi setelah beberapa diantaranya yang 
mendapatkan sertifikasi guru pendidik yang tentu saja semakin menuntut kinerja, komitmen, loyalitas yang lebih baik sebagai guru yang profesional. Pegawai Negeri Sipil (PNS) dalam pandangan masyarakat luas selama ini dianggap mempunyai kinerja yang rendah terhadap tugas dan pekerjaannya termasuk pegawai di lingkungan SLB Negeri 1 Bantul.

Mengingat begitu pentingnya kinerja pegawai untuk kesuksesan instansi ataupun untuk kepentingan pegawai itu sendiri, maka pihak instansi akan berusaha keras untuk meningkatkan kinerja guru PNS di SLB Negeri 1 Bantul. Dalam upaya meningkatkan kinerja pegawai secara efektif perlu kiranya instansi mengetahui faktor-faktor apa saja yang mempengaruhi kinerja. Saat ini masih banyak dipahami kinerja pegawai yang jelek atau buruk berarti pegawai tersebut tidak mempunyai kemampuan ketrampilan atau inisiatif untuk mengerjakan pekerjaannya. Lebih parahnya lagi apabila masih ada saja instansi yang beranggapan yang sama dengan pandangan orang awam pada umumnya, sehingga dalam upaya meningkatkan kinerja pegawainya juga menjadi tidak tepat karena anggapananggapan tersebut. Padahal kalau dipelajari lebih mendalam ada banyak faktor yang berpengaruh terhadap kinerja pegawai salah satunya adalah kepuasan kerja.

Berdasarkan pengamatan awal dan wawancara yang dilakukan pada guru PNS di SLB Negeri 1 Bantul yang menunjukkan adanya kinerja yang rendah seperti membolos/terlambat kerja terutama setelah datang dan presensi kemudian pulang, pemanfaatan jam kerja yang tidak efektif, unjuk kerja yang seadanya, mengajar terlambat, menyelesaikan tugas terlambat, sering pulang kantor sebelum jam kantor selesai dan lain-lain tersebut dipengaruhi adanya ketidakpuasan pegawai. Terlebih lagi bila dukungan instansi dirasakan belum bisa memberikan kepuasan bagi pegawainya misalnya kesempatan berkarir dan kesejahteraan karyawannya. Kondisi demikian bisa terjadi berlarut-larut bilamana tidak segera diantisipasi, dan dicarikan jalan pemecahannya. Akibatnya kinerja dari instansi menjadi tidak efektif.

Rendahnya kinerja pegawai khususnya Pegawai Negeri Sipil karena gaji yang rendah serta kepuasan kerja yang hanya berorientasi pada kepuasan ektrinsik (Scheiher, Greguras \& Watt, 2004).

Kepuasan kerja merupakan sikap secara umum dan tingkat perasaan positif seseorang terhadap pekerjaannya (Robbins, 2003). Lebih lanjut Greenberg dan Baron (2002) mendefinisikan kepuasan kerja sebagai sikap positif atau negatif yang dimiliki seseorang terhadap pekerjaannya. Realitanya banyak dijumpai pegawai yang kurang memiliki kepuasan terhadap pekerjaannya, ketidakpuasan dalam bekerja merupakan persoalan yang harus ditangani secara serius oleh pihak instansi. Tiffin (dalam As'ad, 2004) berpendapat bahwa kepuasan kerja berhubungan erat dengan sikap dari karyawan terhadap pekerjaannya sendiri, situasi kerja, kerjasama antara pimpinan dengan sesama karyawan. Hal ini sangat penting karena pegawai yang tidak mendapat kepuasan dalam bekerja akan terdorong untuk bekerja seenaknya, unjuk kerja seadanya, datang terlambat, mangkir/bolos kerja, tidak mencintai pekerjaannya, dan bahkan mungkin tidak bisa bertahan ditempat kerjanya. Menurut Tuhumena (2004), jika tingkat kepuasan kerja pegawai atau karyawan itu rendah, maka akan mengakibatkan ketidaklancaran organisasi dan proses produksi yang dikarenakan tingginya tingkat keterlambatan dan kemangkiran serta tingginya tingkat keluar masuk karyawan.

Banyak sekali faktor-faktor yang mempengaruhi kinerja pegawai dalam 
suatu instansi. Berdasarkan data-data dan uraian di atas, faktor kepuasan kerja itulah yang diduga berpengaruh terhadap kinerja pegawai. Oleh karena itu maka perlu pembuktian secara ilmiah dan kajian secara mendalam mengenai hal itu. Dalam upaya meningkatkan kinerja pegawai untuk mencapai tujuannya maka kajian ini sangat menarik. Kiranya penting untuk meneliti pengaruh kepuasan kerja terhadap kinerja pegawai dalam instansi mengingat peran pentingnya pegawai tersebut bagi tercapainya tujuan-tujuan instansi. Berdasarkan latar belakang dan identifikasi masalah tersebut, maka dapat dirumuskan pertanyaan penelitian yaitu "Bagaimanakah hubungan kepuasan kerja terhadap kinerja pada guru Pegawai Negeri Sipil (PNS) di SLB Negeri 1 Bantul?”.

Penelitian ini bertujuan untuk mengetahui secara empiris hubungan antara kepuasan kerja dengan kinerja guru Pegawai Negeri Sipil (PNS) di SLB Negeri 1 Bantul. Hipotesis yang diajukan adalah terdapat hubungan yang positif antara kepuasan kerja terhadap kinerja guru Pegawai Negeri Sipil (PNS) di SLB Negeri 1 Bantul. Semakin tinggi tingkat kepuasan kerja maka semakin tinggi pula kinerjanya dan semakin rendah tingkat kepuasan kerja maka semakin rendah pula kinerjanya.

\section{METODE PENELITIAN}

Penelitian dilaksanakan di SLB Negeri 1 Bantul di Jalan Wates km 3 Yogyakarta. Jumlah subjek yang dijadikan penelitian adalah 29 orang guru Pegawai Negeri Sipil (PNS). Subjek yang digunakan dalam penelitian ini mempunyai kharakteristik sebagai berikut: 1) Berstatus sebagai pegawai tetap, 2) Telah bekerja di instansi yang bersangkutan minimal 1 tahun.

Kinerja pada pegawai diukur dengan Skala Kinerja yang merupakan skala yang disusun oleh penulis sendiri yang mengacu pada aspek-aspek kinerja menurut Mitchell (1989) yaitu quality of work (kualitas kerja), promptness (ketepatan waktu), initiative (inisiatif), capability (kemampuan), dan communication (komunikasi). Hasil analisis terhadap 40 aitem Skala Kinerja setelah diseleksi dan dilakukan penyetaraan menunjukkan ada 15 aitem yang memiliki koefisien korelasi aitem $\geq$ 0,30 sehingga dinyatakan valid. Skala Kinerja memiliki koefisien korelasi aitem total bergerak antara 0,385 sampai dengan 0,838 . Koefisien reliabilitas Skala Kinerja adalah 0,929 artinya alat tersebut handal dan dapat digunakan sebagai alat pengumpul data dalam penelitian.

Kepuasan kerja pada karyawan diukur dengan Skala Kepuasan Kerja yang merupakan skala yang disusun oleh penulis sendiri yang mengacu pada aspek-aspek kepuasan kerja menurut Smith, Kendall, dan Hullin (Luthans, 1992) yang terdiri dari lima aspek yaitu aspek pekerjaan itu sendiri, aspek gaji, aspek supervisi, aspek promosi, dan aspek rekan kerja. Hasil analisis terhadap 40 aitem Skala Kepuasan Kerja setelah diseleksi dan dilakukan penyetaraan menunjukkan ada 20 aitem yang memiliki koefisien korelasi aitem $\geq$ 0,30 sehingga dinyatakan valid. Skala Kepuasan Kerja memiliki koefisien korelasi aitem total bergerak antara 0,485 sampai dengan 0,909. Koefisien reliabilitas Skala Kepuasan Kerja adalah 0,956 artinya alat tersebut handal dan dapat digunakan sebagai alat pengumpul data dalam penelitian.

Analisis data yang digunakan adalah teknik korelasi product moment dari Pearson. Sebelum melakukan analisis data menggunakan teknik korelasi product moment, terlebih dahulu dilakukan uji asumsi yang meliputi uji normalitas dan uji linearitas. Analisis data dilakukan dengan menggunakan program Statistik SPSS for Windows Release 17.0. 


\section{HASIL DAN PEMBAHASAN}

Hasil analisis data menunjukkan adanya korelasi positif yang sangat signifikan antara kepuasan kerja dengan kinerja pada guru PNS $\left(r_{\mathrm{xy}}=0,551 ; p=0,001\right)$. Artinya semakin tinggi kepuasan kerja yang dirasakan, maka kinerjanya juga semakin tinggi dan sebaliknya semakin rendah kepuasan kerja yang dirasakan maka kinerjanya juga semakin rendah.

Peneliti juga melakukan analisis untuk mengetahui besarnya sumbangan atau peranan variabel bebas dalam mempengaruhi variabel tergantung. Hasil analisis koefisien determinan $\mathrm{R}^{2}=0,304$, hal ini menunjukkan bahwa kepuasan kerja memberi pengaruh sebesar 30,4\% terhadap kinerja, dengan demikian masih terdapat $69,6 \%$ pengaruh faktor lain yang tidak teridentifikasi dalam penelitian. Faktor-faktor lain yang diduga berpengaruh terhadap kinerja pegawai menurut Simamora (1995), Gibson, dkk. (2000) dan As'ad (2004) dikelompokkan menjadi faktor individu, faktor psikologi dan faktor organisasi. Faktor individu yang meliputi kemampuan, ketrampilan, latar belakang dan demografis. Faktor psikologi yang meliputi persepsi, sikap, kepribadian, belajar, dan motivasi. Faktor organisasi yang meliputi sumber daya, kepemimpinan, imbalan, struktur dan desain pekerjaan, sistem pengawasan serta karir.

Temuan dalam penelitian di atas mendukung pendapat para ahli sebelumnya seperti penelitian Thomas, Tram, dan O'Hara (2006) yang menunjukkan bahwa kinerja karyawan dipengaruhi oleh kepuasan kerja. Kepuasan kerja yang terpenuhi baik intinsik atau ekstinsik akan membuat karyawan lebih termotivasi meningkatkan kinerjanya. Timpe (2001) menambahkan bahwa faktor kepuasan kerja dapat mempengaruhi kinerja individu dalam suatu organisasi. Menurut Simamora
(1995), Gibson, dkk. (2000) dan As'ad (2004) faktor yang mempengaruhi kinerja dikelompokkan menjadi faktor individu, faktor psikologi dan faktor organisasi dan di dalam faktor psikologi salah satunya adalah kepuasan kerja. Dari beberapa teori tersebut disimpulkan bahwa kinerja pegawai dipengaruhi oleh kepuasan kerja yang dirasakan. Kepuasan kerja itu sendiri adalah perasaan individu terhadap pekerjaannya. Perasaan ini berupa suatu hasil penilaian mengenai seberapa jauh pekerjaannya secara keseluruhan mampu memuaskan kebutuhannya.

Sceiher, dkk. (2004) lebih lanjut menjelaskan rendahnya kinerja pegawai khususnya Pegawai Negeri Sipil karena gaji yang rendah serta kepuasan kerja yang hanya berorientasi pada kepuasan ektrinsik. Tiffin (As'ad, 2004) berpendapat bahwa kepuasan kerja berhubungan erat dengan sikap dari karyawan terhadap pekerjaannya sendiri, situasi kerja, kerjasama antara pimpinan dengan sesama karyawan. Hal ini sangat penting karena pegawai yang tidak mendapat kepuasan dalam bekerja akan terdorong untuk bekerja seenaknya, unjuk kerja seadanya, datang terlambat, mangkir/bolos kerja, tidak mencintai pekerjaannya, dan bahkan mungkin tidak bisa bertahan ditempat kerjanya. Tuhumena (2004) menambahkan jika tingkat kepuasan kerja pegawai atau karyawan itu rendah, maka akan mengakibatkan ketidaklancaran organisasi dan proses produksi yang dikarenakan tingginya tingkat keterlambatan dan kemangkiran serta tingginya tingkat keluar masuk karyawan.

Hasil observasi dan wawancara yang dilakukan subjek penelitian menunjukkan adanya kinerja yang rendah seperti membolos/terlambat kerja terutama setelah datang dan presensi kemudian pulang, pemanfaatan jam kerja yang tidak efektif, unjuk kerja yang seadanya, mengajar 
terlambat, menyelesaikan tugas terlambat, sering pulang kantor sebelum jam kantor selesai dan lain lain yang semua perilaku tersebut terkait dengan ketidakpuasan pegawainya. Hasil tersebut didukung oleh Lawler (Munandar, 2008)) dimana individu akan puas dengan bidang tertentu dari pekerjaan mereka, misalnya rekan kerja, atasan, upah, gaji dan sebagainya, jika jumlah bidang yang mereka alami adalah yang seharusnya mereka peroleh karena telah melaksanakan pekerjaannya sama dengan jumlah yang benar-benar mereka peroleh. Implikasi teori ini adalah seseorang akan menyesuaikan kontribusinya sesuai dengan tingkat kepuasan yang diperolehnya. Jumlah dari bidang yang dipersepsikan individu tergantung dari bagaimana individu tersebut mempersepsikan pekerjaannya.

Berdasarkan kategori kedua variabel penelitian, pada variabel kinerja, dapat dilihat bahwa tidak ada subjek pada variabel kinerja berada dalam kategori rendah dan hanya $1 \quad(3,45)$ subjek yang berada dalam kategori sedang. Mayoritas subjek pada variabel kinerja berada pada kategori tinggi yang berjumlah 28 orang atau sebesar 96,55 \%. Sedangkan untuk variabel kepuasan kerja dapat dilihat bahwa tidak ada subjek pada variabel kepuasan kerja yang berada dalam kategori rendah. Mayoritas subjek yang memiliki rasa kepuasan kerja terdapat pada kategori sedang dan tinggi yang berjumlah masingmasing $9(31,03 \%)$ dan $20 \quad(68,97 \%)$ subjek, sehingga dapat disimpulkan bahwa mayoritas subjek yang memiliki kinerja dan kepuasan kerja berada dalam kategori tinggi.

Hasil analisis kategorisasi skala tersebut bertolak belakang dan tidak sesuai dengan data observasi dan wawancara yang diperoleh peneliti di lokasi penelitian dari kepala sekolah dan beberapa guru yang menjadi subjek penelitian. Fenomena tidak adanya subjek yang berada dalam kategori rendah dan semua subjek berada alam kategori sedang dan tinggi menjadi menarik untuk dibahas. Realita di lapangan menunjukkan bahwa banyak pegawai yang memiliki kinerja yang rendah, hal itu ditunjukkan perilaku membolos/terlambat kerja terutama setelah datang dan presensi kemudian pulang, pemanfaatan jam kerja yang tidak efektif, unjuk kerja yang seadanya, mengajar terlambat, menyelesaikan tugas terlambat, sering pulang kantor sebelum jam kantor selesai dan lain-lain.

Permasalahan di atas menjadi kelemahan dalam penelitian ini yang disebabkan oleh adanya faking good yaitu ketika proses pengambilan data penelitian yang berupa skala, pilihan jawaban yang dipilih oleh para pegawai adalah jawaban yang positif atau jawaban yang favorable meskipun jawaban tersebut tidak sesuai dengan keadaan karyawan yang sebenarnya. Munculnya faking good itu sendiri disebabkan oleh tidak adanya pengawasan yang dilakukan peneliti selama proses pengambilan data karena banyak pegawai yang tidak semuanya bisa meninggalkan pekerjaannya pada saat penyebaran skala dan ada pula yang tidak berada ditempat kerjanya, sehingga untuk proses pengisian data skala yang disebarkan harus ditinggalkan dan dititipkan pada kepala bagian/stafnya untuk kemudian didistribusikan oleh pihak instansi dan kemudian diambil kembali sampai skala tersebut terisi semua.

Menurut Anastasi dan Urbina (2007) dalam pengisian skala yang diisi sendiri, partisipan memiliki kecenderungan untuk menjawab kearah yang lebih baik (faking good), kecenderungan partisipan untuk faking good muncul dengan alasan untuk melindungi diri sendiri, menghindari kritik, konformitas sosial, serta keinginan untuk diterima secara sosial karena permasalahan mengenai kepuasan kerja dan penilaian 
kinerja menjadi hal yang sensitif bagi pegawai. Hal tersebut mempunyai dampak dalam pengisian item dalam alat ukur dan menjadi kelemahan dalam penelitian ini.

\section{KESIMPULAN}

Berdasarkan hasil analisis data dapat disimpulkan bahwa terdapat korelasi positif yang sangat signifikan antara kepuasan kerja dengan kinerja pada guru Pegawai Negeri Sipil di SLB Negeri 1 Bantul ( $\left.r_{\mathrm{xy}}=0,551 ; p=0,001\right)$. Semakin tinggi kepuasan kerja pada guru yang dirasakan, maka akan semakin tinggi kinerjanya. Semakin rendah kepuasan kerja guru yang dirasakan, maka akan semakin rendah kinerjanya. Kepuasan kerja memberikan sumbangan efektif terhadap kinerja sebesar 30,4 \%. Hasil tersebut menunjukkan bahwa variabel kepuasan kerja cukup dominan dalam mempengaruhi kinerja guru Pegawai Negeri Sipil di SLB Negeri 1 Bantul.

Hasil penelitian ini dapat dijadikan sebagai acuan dan pengetahuan bahwa kepuasan kerja mempunyai pengaruh yang cukup besar untuk meningkatkan kinerja pegawai sehingga upaya meningkatkan kinerja tersebut dilakukan melalui peningkatan kepuasan utamanya adalah peningkatan pada aspek-aspek yang signifikan terhadap kinerja tersebut. Selain itu bagi penelitian selanjutnya, agar peneliti melakukan penelitian dengan melibatkan faktor-faktor lain yang mempengaruhi kinerja agar penelitian yang dilakukan dapat memberikan manfaat yang lebih dalam dan luas bagi dunia pendidikan dan juga agar teori-teori mengenai kinerja menjadi semakin kuat. Selain itu karena penelitian ini dilakukan di organisasi non profit, peneliti selanjutnya dapat meneliti pada organisasi profit atau perusahaan yang berbeda iklim dan karakteristiknya.

\section{DAFTAR PUSTAKA}

Anastasi, A. \& Urbina, S. (2007). Psychological testing. Edisi ketujuh. Jakarta: PT Indeks.

As'ad, M. (2004). Seri ilmu sumber daya manusia psikologi industri. Edisi Keempat. Cetakan kesembilan. Yogyakarta: Liberty.

As'ad, M. (2004). Psikologi industri. Edisi keempat. Yogyakarta: BPFE.

Gibson, J. L, Ivancevich, J. M, \& Donelly, J.H. (2000). Organizations, behavior, structure, processes. Edisi 11. Chicago: Irwin.

Greenberg, J. \& Baron, R. A. (2002). Behavior in organization: understanding and managing the human side of work (6th ed), Saddle River, NJ: Printice hall.

Kusmana, U. (2012). Kata Menpan, hanya 5 persen pns yang memiliki kompetensi.http://birokrasi.kompasi ana.com/2012/03/01/kata-menpanhanya-5-persen-pns-yang-memilikikompetensi-443214.html. Diunduh 12 Januari 2013.

Luthans, F. (1992). Organizational behavior. Tokyo: Mc Graw-Hill International Book Co.

Mitchell, T. R. (1989). People in organisation: An introduction to organizational behaviour. New York: McGraw Hill Book

Mizan. (2013). PNS berkinerja buruk akan dipecat. http://www.menpan.go.id/ regulasi/perundangundangan/peratu ran pemerintah/file/1580-pp-2006no-033. Diunduh 01 Oktober 2013. 
Munandar, A. S. (2008). Psikologi industri dan organisasi. Jakarta: UI-Press.

Robbins, S. P. (2003). Perilaku organisasi: Konsep, kontroversi, aplikasi (terjemahan Hadyana Pujaatmaka). Jilid I. Jakarta: Prenhalindo.

Rotundo, M. \& Sackett, P. R. (2002). the relative importance of task, citizenship, and counterproductive performance to global ratings of job performance a policy-capturing approach. Journal of Applied Psychology, 87 (1), 66-80.

Scheiher, D. J., Greguras, G. J., \& Watt, J. D. (2004). Reexamining the job satisfaction-performance relationship: The complexity of attitudes. Journal of Applied Psychology, 89 (1), 165-177.

Simamora, H. (1995). Manajemen sumber daya manusia. Yogyakarta: STIE YKPN.

Suara Pembaharuan. (2011). Kinerja dan produktivitas birokrasi indonesia buruk.http://sp.beritasatu.com/ekon omidanbisnis/kinerja-danproduktivitas-birokrasi-indonesia- buruk/10863. Diunduh 12 Januari 2013.

Thomas S.Y., Tram, S., \& O'Hara L. A. (2006). Relation of employee and manager emotional intelligence to job satisfaction and performance. Journal of Vacational Behaviour, 68, 461-473.

Timpe, A. D. (2001). Seri ilmu dan seni manajemen bisnis: Motivasi pegawai. Jakarta: PT. Elek Media Komputindo

Tuhumena, H. A. B. (2004). Hubungan antara kondisi kerja dengan kepuasan kerja karyawan bagian produksi. Jurnal Psikologi, 14 (2), 53-58.

Vande W. D., Heslir, P. A., \& Latham, G. P. (2005). The effect of implicit person theory on performance appraisals. Journal Applied Psychology, 90 (5), 842-856.

Yukl, G.A. (2009). Kepemimpinan dalam organisasi. Penerjemah: Budi Suprianto. Edisi Kelima. Jakarta: PT Indeks 